\title{
ENQUETE
}

\section{KAN DYSTOPIER GØRE VERDEN TIL ET BEDRE STED?}

INGER SJØRSLEV

Jeg åbner øjnene. Åbner dem, lukker dem ... som galler... Solen foran os. Den flammende ildkugle er på vej op. Ikke noget at sige til at de første mennesker lagde sig på knæ for den. Hvorfor stoppede vi, hvornår stoppede vi med at tilbede solen ...

Det er højst interessant. råber Diago ... Ja, det råber han. Han råber til mig. At jeg skal høre dette.

At hvad?

Vi mennesker gør det samme. Kan du ikke se det?

Hvad?

Mennesket gør som algerne ... Vi skaber betingelserne for højerestående liv samtidig med at vi ... udrydder os selv ... det er livets vej ...

homo sapiens var blot en bro... en bro mellem biologien og teknologien ...

haha, ja, livet vandrer hen over broen nu, ser du det, det myldrer allerede... det biologiske liv vandrer over broen, der er intet at gøre ...

Sådan står der på en af de sidste sider i den danske digter Theis Ørntofts dystopiske generationsroman fra 2018 med den ikke-tilfældige titel Solar. I slutningen af bogen, hvor vi ikke rigtig ved, om hovedpersonen er på et ugelangt crack-trip, bare lader sin dystopiske fantasi være i frit fald, eller om noget af det sker i virkeligheden, beskriver han mennesket som en overgangsfigur i universets historie.

Bogen inspirerede til at spørge, om sådanne dystopiske fremmaninger af mennesket $\mathrm{i}$ vor tid kan bidrage til at gøre verden til et bedre sted. Kan dystopier gøre verden til et bedre sted? Jeg ville godt kunne fremsætte den påstand, at det kan de, for i denne enquete bygger jeg ikke på veldokumenteret egen empiri. Heldigvis har jeg ikke selv noget empirisk belæg for, at verden er ved at gå under. Men måske er der andre, der har.

En dystopi er en pessimistisk fortælling om, hvor galt det kan gå i verden. En tænkt historie, men som regel delvist byggende på kendsgerninger, som i histo- 
rien ekstrapoleres fremad i tid, således at man ender et sted, hvor det går frygteligt galt. Dystopien kan give varsler om altings undergang.

Først tænkte jeg altså, at overskriften for denne enquete skulle være en påstand: Dystopier kan gøre verden til et bedre sted. Men så kom jeg i tvivl. Kan de nu også det? Det er bedre med et spørgsmål: Kan dystopier nu også gøre verden til et bedre sted? Og hvis ikke, hvad skal vi så med dem?

Vi har tilsyneladende brug for dystopier. Ikke kun som dramatisk udmalede scenarier, der kan pirre vores frygt, men også som advarsler, der vækker vores vagtsomhed og evne og motivation til at ændre på tingene. For - som man siger - hvis man er på vej et sted hen, så ender man dér, medmindre man ændrer retning. Og at verden er på vej et galt sted hen, dét er der så rigeligt belæg for. Som oplagte eksempler er der klimaforskningens overbevisende dokumentation af, at en del klimaforandringer er menneskeskabte, og at der vil ske drastiske ødelæggende forandringer, hvis vi ikke ændrer livsstil radikalt (Gore 2006; Hastrup 2013). Desuden har vi økonomen Thomas Pikettys forskning i kapitalismens konsekvenser i form af stigende ulighed (Piketty 2014) og dertil det omsiggribende politiske vanvid og magtens mere eller mindre skjulte indgriben over for kritiske røster, også i demokratiske samfund. Dertil kommer underminering af gode værdier som, at sandhed er bedre end løgn og tvivl bedre end fundamentalistisk skråsikkerhed, at diversitet er bedre end ensartethed, at kultur er en bærende faktor i menneskers og samfunds liv og modstandskraft, at religions-

og trosfrihed er en menneskeret, og at menneskerettighederne i det hele taget er værd at kæmpe for.

\section{Pessimismens paradoksale tidsalder}

Pessimismen har så rigeligt at nære sig af, og dystopierne trives da også godt i vor tid.

Alligevel må man spørge, hvorfor mon? Ser vi nemlig et øjeblik på nogle faktuelle forhold, således som de er undersøgt og fremlagt af FN, ser det mere sammensat ud. I en rapport fra UNDP, United Nations Development Programme, kan man læse, at folk i de vestlige lande tror, at forholdene i verden er værre, end de er. Samme sted præsenteres FN's 17 verdensmål, passende ambitiøse på verdens vegne. I år 2030 skal fattigdom og sult være helt afskaffet. Og her viser det sig, at den andel af verdens befolkning, der klassificeres som fattig, faktisk allerede er faldet, nemlig siden 1990 'erne fra 38 procent til 10 procent (UNDP 2016:7-8). Om godt 10 år skal der ikke være nogen fattige i verden. Alle skal i skole, også piger, infrastruktur skal forbedres på bæredygtige måder, og ulighed skal mindskes. Men hvor de øvrige verdensmål forekommer den mindre dys- 
topisk indstillede verdensborger nogenlunde realistiske, er spørgsmålet, om den politiske enighed rækker til det med at mindske uligheden. For samtidig med at menneskeheden har det historisk godt, ser vi ikke megen politisk vilje til at reducere verdens absurd koncentrerede rigdomme - koncentreret hos enkelte firmaer, familier og personer. Vi ser nationalstater lukke sig om sig selv. Vi ser flygtningestrømme mod Europa, og vi ser, at flygtningestrømmene ind i de rige velfærdssamfund af nogle betragtes som en alvorlig trussel og tidens største problem. Nationalkonservatismen breder sig. Senest har man i den offentlige debat kunnet høre det synspunkt fremsat, at humanisme er so last year. 1990'ernes menneskerettighedsdiskurser og relative åbenhed over for folk udefra, der måtte have behov for et nyt liv inden for vores velfærdssamfund, betragtes nu nærmest som en anormalitet, en irrationel holdning i tiden, en hippiesensitivitet, som ikke er båret af fornuft og realisme. Nu må fornuften råde, og „fornuften“, hævdes det, siger selvbeskyttelse. Der udmales scenarier af fremtidstrusler mod vores velfærd, vores værdier og historiske selvbestemmelse.

Den slags kunne godt få pessimismen frem i selv den mest optimistiske på menneskehedens vegne. Men dystopier, der taler om humanismens forsvinden og en instrumentel fornufts sejr eventuelt kombineret med et totalitaristisk politisk styre, synes alligevel at have været mere fremherskende for et halvt århundrede siden. Dengang gav ikoniske dystopiske romaner som George Orwells 1984 (2016 [1949]) os et billede af et totalitært a-humanistisk samfund. Dagens dystopier går mere på klimatisk undergang a la filmen The Road fra 2009 og den roman, den bygger på, Vejen, fra 2008 (McCarthy 2008), eller de går på teknologisk løbenløbsk a la HBO-serien Westworld fra 2016 eller den nyligt nyversionerede Blade Runner, som oprindeligt er fra 1982. En undtagelse er den dystopisk-feministiske HBO-serie Tjenerindens fortoelling (The Handmaid's Tale), bygget på en roman fra 1985 af Margaret Atwood (2017). Den skal jeg vende tilbage til.

Billedet er sammensat, men ingen tvivl om, at lige meget hvor gode fremskridtsresultater for verden FN kan påvise, og hvor optimistiske verdensmål der opstilles, lever dystopierne godt og florerer i stor stil i litteratur og film. Et hurtigt googleopslag på dystopiske film gav en liste på omkring 200 siden 1960'erne. ${ }^{1}$

Er det måske sådan, at vi paradoksalt nok lever i dystopiernes tidsalder, samtidig med at det på mange, om ikke alle, måder går faktuelt bedre end nogensinde? ${ }^{2}$ Hvordan kan det i så fald hænge sammen? Og hvis der er noget om det, hvad kan den antropologiske fagindsigt så bidrage med til forståelse af dette paradoks?

Vi ved måske mere om, hvad der truer os, end tidligere generationer. Vores frygt og ængstelse cirkulerer og kommunikeres ud som aldrig før. Og trods åbenlyse fremskridt for menneskeheden er der jo altså nok af faktuelle grunde til bekymring. Som FN's tidligere generalsekretær har sagt det, er vi ganske vist den første 
generation, der kan afskaffe fattigdom, men vi er også den sidste, der kan gøre noget ved klimaudfordringerne. Gør vi ikke dét, er vi - ja, hvad, fordømte? Visse dystopier vil hævde det. I Christopher Nolans film Interstellar fra 2014 ender helten efter en hæsblæsende rejse gennem diverse ormehuller sammen med sin datter i en teknologisk skabt kunstig verden, ren og frugtbar, et sted ude i rummet, mens Kloden, som vi kender den, er forladt som ubeboelig, gået under i diversitetsdød og gold forurening. Måske er det ikke tilfældigt, at det er landbrug og monokultur, der synes at være den store skurk i denne film, hvor man ser halvvisne majsmarker, så langt øjet rækker, i den ikke helt urealistisk dystopiske fantasi om en fremtidsverden, der kun kan fortsætte uden for en ubeboelig klode. Landbrugets skift fra småbrug til industri over det meste af kloden er allerede en kendsgerning, og de ødelæggende konsekvenser heraf er kendte.

\section{Individets forsvinden - en dystopi?}

Dystopier ligger altså i tiden. Fiktionens verden behandler de samme temaer som antropologien med sin forskning i den antropocæne tid, vi lever i; med sine posthumanistiske teorier, der sætter mennesker ind i netværk med ikke-menneskelige størrelser og dropper individer til fordel for de relationelt definerede divider (Strathern 1988). En glimrende idé i øvrigt, som netop antropologien har et stort empirisk materiale til at belyse gennem sin viden om relationelt definerede (in)divider, hvad enten relationerne er til andre mennesker eller til ting. Her har antropologien indset nødvendigheden af at forfølge Foucaults spørgsmål om, hvorvidt mennesket, som vi kender det i dag, vil forsvinde, „visket bort, som et ansigt af sand ved havets bred" (Foucault 2002 [1966:447).

Er det måske allerede sket? Er vi, som Ørntoft skriver, forbi det enestående individ, det singulære subjekt som genstand for forskning, sociologisk, medicinsk og humanistisk? Skal antropologien som læren om mennesket skifte navn tilja, til hvad? Læren om sværmintelligenser? Cyborgologi? Antropologien er jo læren om relationer, nok så meget som det er læren om det enkelte menneske. Det er en veletableret sandhed i faget. Intet menneske er en ø, som digteren John Donne sagde. Vi er forbundne, ikke bare med hinanden i slægtskab og netværk, men også med tingene omkring os, med teknologi og guder, ånder og aber, planter og planeter, med naturerne (i flertal, ja) og universet. Og vi er i gang med - eller må nødvendigvis se at få udviklet - vores planetariske bevidsthed, som allerede filosoffen Kant gjorde os opmærksom på tilbage i 1700-tallet.

Der er bare ikke en god idé, hvis det sker på bekostning af humanismen og i et misforstået og radikalt opgør med oplysningstidens værdier. Et godt spørgsmål at stille til den antropologiske fagdisciplin i lyset af dystopiernes popularitet kunne 
derfor være: Hvordan bevarer vi humanismen i betydningen anerkendelsen af det enkelte menneskes værdi med dets umistelige rettigheder, som menneskeretsdeklarationerne understreger, samtidig med at indsigterne i de relationelt definerede (in)divider bringes med ind i billedet?

I Ørntofts digteriske billede er det spørgsmålet, om homo sapiens virkelig bare var en bro mellem biologien og teknologien. I Foucaults optik er spørgsmålet, om vi lever i en epoke, hvor mennesket som individuel størrelse allerede er forsvundet som en tegning i sandet, uden at vi har opdaget det. Hvordan det end forholder sig, må det være en af antropologiens grundopgaver at fastholde sin tradition for at have det menneskelige i centrum af sit interesse- og undersøgelsesfelt. Hele det menneskelige felt altså, men ikke nødvendigvis mennesket i ental og i den isolerede individ- og subjektforståelse, der bliver udfordret fra så mange sider. Fra teknologiens og biologiens, ja, men også fra socialitetens og fra nye erkendelser af, hvad relationer og netværk ud til andre størrelser betyder. Opgaven må være at vise, at individets forsvinden ikke skal ses som en dystopi, men som en udvidelse af vores forståelse af det menneskelige. Det ville være både i nutidens og oplysningstidens ånd. Hvis dystopiernes påpegninger af de menneskelige kroppes slørede grænser bruges i dén retning, kan de meget vel bidrage til at gøre verden til et bedre sted.

\section{Totalitarismen som dystopi og dens modstand: Tjenerindens fortælling}

Fra en anden vinkel kan man kritisk spørge, hvad der bliver af antropologiens bestræbelser på at se dynamikkerne i det sociale og globale liv som konstruktive og opfindsomme tilpasninger til mere eller mindre umulige vilkår. Hvad bliver der af at se på folks oprør mod stærke overmagter, på samfunds modstandsdygtighed? Lad os med dette spørgsmål vende tilbage til den dystopiske HBO-serie The Handmaid's Tale. Tjenerindens fortolling, som er titlen i den danske oversættelse, er nemlig ikke bare et intelligent feministisk indslag i dystopiernes populærkulturelle verden. Det er også historien om livsbegærets og frihedens kamp på den uhyggelige baggrund af det, Marx og Engels i 1884 kaldte for kvindekønnets verdenshistoriske nederlag. Her har vi statens fulde kontrol med de reproduktive kræfter, som kvindekønnet indtil videre har inkarneret. En biopolitisk totalitarisme i en uhyggeligt overbevisende dystopi med masser af konnotationer til nutidens allerede eksisterende voldelige kontrolformer, understøttet af fundamentalistisk religion, fra abortforbud til barbariske kropslige afstraffelser.

Dér hvor det hæslige fundamentalistiske og totalitaristiske samfund ved navn Gilead er i fortællingen, dér er vi ikke. Vi er tværtimod i en verden, hvor LGBTI 
- lesbiske, bøsser, biseksuelle, transkønnede og interkønnede - vinder nye sejre, og hvor teknologien giver kroppe af diverse køn nye muligheder. Men hvis ressourcen børn, fødsler og dermed nye generationer virkelig skulle vise sig at være alvorligt truet, kan fantasien alt for let følge med ind i den så uhyggeligt æstetisk gennemførte rædselsverden, vi ser i serien. En af denne dystopiske fortællings kvaliteter er, at den viser os, hvad vi har, og hvad vi må sørge for ikke at miste, herunder den kropslige frihed, som er så markant i de flashbacks, der vises til tiden før Gilead, hvor den (køns)politiske frihed er ledsaget af frie kroppe og tøj, der matcher det frie liv, så umanerligt godt spillet af seriens team.

Der er en vis ironi i, at det i 1930'erne var Margaret Meads prisning af de unges erotiske frihed i Samoa, som Schwartz omtaler, der blev til en slags civilisationskritik i den amerikanske verden på et tidspunkt, hvor teenagebegrebet kun lige var blevet opfundet, mens vi nu i vor tid ser Tjenerindens fortcelling som den antropologisk informerede dystopi. En nedgangsfortælling, der forener det politiske med det biologiske, og den reproduktivt orienterede seksualitet som dén afgørende faktor, der viser, at hvis menneskeheden holder op med at kunne reproducere sig, er løbet kørt. Man kunne behandle dette problem anderledes og på en måde, man måske skulle kalde utopisk, ved for eksempel at gå robotvejen og den kunstige befrugtnings vej. Som dog også hurtigt kunne blive til en dystopi. Men i Tjenerindens fortcelling er det geniale, at den biologiske dystopi er sat sammen med en politisk dystopi i form af et totalitært samfund med ekstrem vold og undertrykkelse. Samt oprydning i en forurenet verden som straf, mandestyret mestendels, men det er på sin vis underordnet, for uhyggen ligger i den altomfattende karakter, dette system har, som så fornemt vises i seriens æstetiske side med dragter og kropskontrol, helt ned til samtaler og spadsereture. Det er biopolitik i en rædselsudgave, som måske ikke engang Foucault havde kunnet forestille sig.

\section{En bedre verden via dystopierne?}

Hvordan kan dystopiske fantasier gøre verden til et bedre sted? Hvad kan svarene blive? For det første må man huske på et godt gammelt spejderudtryk: Vær beredt! Hvis vejen frem til noget a la det, dystopierne fremlægger for os, de saglige såvel som de fiktive, hvis den vej virkelig er uundgåelig, så sørg i det mindste for at kende vejen. Dokumentér processen, tro på, at der vil findes en eller anden form for eftertid, så beviset på, at vi dog kendte os selv, om ikke godt nok til at undgå katastrofen, så dog alligevel - at dette bevis har en værdi. Store riger og civilisationer er før gået under i historien, det kan ske igen. Tro på en eller anden form for efterkommere, lad ingen dystopisk fortvivlelse gå så langt, 
at vi siger, det kan være det samme, efter os er der ingenting. Lad os ikke blive historieløse. Den amerikanske litterat og kritiker, postmodernitetens teoretiker Fredric Jameson, har sagt, at det postmoderne bedst forstås som et forsøg på at tænke nutiden historisk i en tid, der ellers har glemt at tænkte historisk (Jameson 1991). Hvis han har ret - og meget i tiden kunne tyde på, at han har ret i det med historieløsheden - så gå imod det, sørg for, at lade den historiske tænkning komme til fuld udfoldelse. Lad efterkommere (!) - i de mest pessimistiske scenarier interplanetare besøgende eller helt nyopstået liv eller måske enkelte overlevende, der begynder forfra som i romanen Vejen (McCarthy 2008) - lad dem have noget at forske i. Efterlad noget om vejen til det, vi blev eller holdt op med at være. I mellemtiden er det måske stadig muligt at undgå de værste virkninger eller endnu bedre: at ændre retning.

Der kommer ikke i sig selv en bedre verden ud af et dystopisk scenarie som det, man af og til hører fremsat af dem, der er mest bekymrede for klimaforandringerne, og som lyder: Glem børnebørn, glem efterkommere. Et dystopisk scenarie, som nærværende enqueteskriver i øvrigt nægter at tro på - lad os bare sige med en vis desperat optimisme. Eller vi skal måske hellere sige voelger ikke at tro på. At sådan et valg har betydning og virkning, har samfunds- og humanvidenskaberne nemlig også vist os. Tanker, tro og repræsentationer har virkninger i den virkelige verden. Det er noget, vor tids filosofi har lært os, at man godt kan tro på. Måske flytter troen ikke ligefrem bjerge, men hvad vi tænker, vælger at tro og fortæller hinanden i viden og kunst og digtning, hører ikke hjemme på en anden planet, end hvad der finder sted i den materielle verden. Dét har sidste del af det 20. århundredes tænkning lært os, og det er en god lære at tage med videre.

Men hvad kan den antropologiske viden ellers bruges til? I invitationen til dette års årlige møde i AAA, den store amerikanske antropologsammenslutning, stiller man spørgsmålet, hvad holisme - den gode gamle etnografiske holisme kan lære os om social forandring i fortiden, nutiden og fremtiden. Og om en antropologisk forståelse kan styrke vores evne til at have visioner for fremtiden. Det er interessant at bemærke, at holismen her bliver genoptaget som et af de helt centrale begreber i den antropologiske tænkning. Samtidig sigtes der tydeligvis nok til noget andet end den klassiske holisme, der er i familie med Mauss' totale sociale faktum. Det nye holismebegreb ser i denne sammenhæng ud til at skulle understrege inddragelsen af andre arter, for der er en flertalsendelse på arter i invitationsteksten. Med den tanke er der givet et bud på en nutidig holistisk forståelse, en forståelse, der inddrager posthumanistiske indsigter i den ikke-selvfølgelige forståelse af det menneskelige subjekt og de hastigt stigende - og stærkt nødvendige - indsigter i karaktererne og virkninger af de forskellige netværk og relationer, menneskelige subjekter befinder sig i, fra arternes til tingenes. 
Et positivt, men forsigtigt, svar på spørgsmålet om, hvorvidt dystopier kan bidrage til en bedre verden, må gå vejen omkring selvrefleksion og selverkendelse som vigtige skridt frem til noget bedre. Eller måske hellere, noget mindre skidt. Det er nemlig ikke en god idé at tale om noget „bedre“ i betydningen en utopisk, lukket verden med den store risiko for at blive totalitær, som historien har vist os, man finder i megen utopisk tænkning. Hellere end den fuldkomne utopi må vi ønske os færre dårligdomme, mindre sociale onder for menneskeheden. Mindre ulighed for eksempel, med en bedre fordeling af ressourcerne og mindre ødelæggende udnyttelse af dem.

FN's verdensmål ville passe udmærket ind i sådan en tankemodel. De er nemlig hverken utopiske eller dystopiske, men pragmatiske på et både humanistisk og planetarbevidst grundlag. Selvom det er aldeles uspektakulært og ikke nær så underholdende som kunstens, litteraturens og filmens dramatiseringer, får man lyst til at tale stilfærdigt for denne pragmatisme. Der må gerne råbes højt om den. Det stilfærdige ligger i de forholdsvis afdæmpede fremtidsvisioner, hvad fantasifulde scenarier angår.

Det andet spørgsmål, jeg har rejst, er, om antropologiens redskaber kan bruges til at belyse og analysere den rolle, dystopiernes floreren i vor tid spiller. Så snart vi støder på et paradoks i det sociale liv, plejer vi at sige, at vi har fundet guld. Altså analytisk guld. Det paradoks, det er, at verden faktisk på mange måder bliver et bedre sted at være, og dystopierne samtidig er så populære, det kunne med en vis optimisme ses som et udtryk for en stigende refleksionsevne, en styrket bevidsthed om de værdier, vi har, og som der må kæmpes for.

Man kan læse det som jubeloptimisme, men som allerede antydet: Ordet skaber det, det nævner, som salig Grundtvig sagde. Oversat til nutidigt antropologsprog: Tankens og ordenes kraft indvirker på realiteterne. Jeg orker næsten ikke at gentage det forslidte terapislogan: Tænk positivt! Men den opmærksomme læser har måske allerede spottet, at det er noget i dén retning, jeg er ude i. Dog ikke uden denne afgørende tilføjelse: Tænk kritisk!

Er antropologien så særligt velegnet til dét? Måske ikke umiddelbart positiv, men i hvert fald kritisk. Den bør være det! Den er velegnet til historisk bevidsthed, paradoksanalyse og strategisk repræsentations- og ordbrug samt naturligvis opmærksomhed på det menneskelige i alle dets krøllede netværksagtige former.

Det er ikke svært at se, hvordan antropologiens teorier og indsigter kan belyse rædselsscenariet i Tjenerindens fortcelling, som er en historie om kontrol med et samfunds evne til at reproducere sig, om magtens former - både de formelle og de uformelle - og i serieudgaven af romanen måske ikke mindst om, hvordan rum, æstetik og kropsdisciplinering afspejler samfundets magtstrukturer. 
Antropologien har redskaberne til at undersøge de modsætninger mellem folks selvforståelser og deres liv i praksis, der sommetider fremstår som paradokser. Hvis dystopier ses som negativ selvforståelse, måske båret af en forståelig frygt for fremtiden, må de sammenholdes med mere konkrete eksempler på, hvordan det sociale liv tager sig ud, sådan som vi har tradition for at gøre det i antropologien. At det tager sig overordentlig forskelligt ud, alt efter hvor på kloden man lever, og at de dystopiske forestillinger synes at trives godt der, hvor livet er bedst og mest sikkert, nemlig blandt middelklassen i den vestlige verden, gør ikke paradokset mindre.

Der er større spørgsmål at besvare, end hvad der kan rummes inden for denne enquete, så det må ende med en opfordring til at tænke videre over paradokset, en opfordring, der er båret af en optimistisk overbevisning om, at man med udnyttelse af antropologiens analytiske redskaber vil kunne komme dybere ned i gåden om, hvorfor dystopierne trives så godt på alle kanaler - de videnskabelige såvel som i fiktionens verden, samtidig med at verden faktisk på så mange måder allerede er blevet et bedre sted at være. Indtil videre.

\section{Noter}

1. Fredric Jamesons Archaeologies of the Future fra 2005 kan anbefales varmt som en omfattende litterær analyse af vigtige værker fra især science fiction fra det seneste halve århundrede og en interessant diskussion af såvel utopiers som dystopiers historie.

2. Den svenske læge og statistiker Hans Rosling er måske den bedst kendte repræsentant for det synspunkt, at det går fremad i verden. I en stribe populære og velformidlede foredrag samt senest i bogen Factfulness (2018) har han ved hjælp af statistik og en lang række eksempler vist, at det står bedre til i verden, end de fleste af os går og tror, og han hævder, at medierne er medskyldige $\mathrm{i}$ et negativt syn på verdens tilstand.

\section{Litteratur}

Atwood, Margaret

2017 [1985] Tjenerindens fortælling. København: Lindhardt og Ringhof.

Foucault, Michel

2002 [1966] Ordene og tingene. En arkæologisk undersøgelse af videnskaberne om menesket. København: Gyldendals Bogklubber.

Gore, $\mathrm{Al}$

2006 The Inconvenient Truth. The Planetary Emergency of Global Warming and What We Can do about It. New York: Rodale.

Hastrup, Kirsten

2013 Anthropological Contributions to the Study of Climate. Past, present, Future. WIREs Climate Change 4:269-81. 
Jameson, Fredric

1991 Postmodernism, or, The Cultural Logic of Late Capitalism. London: Verso.

2005 Archaeologies of the Future. The Desire Called Utopia and Other Science Fictions. London: Verso.

McCarthy, Cormac

$2008 \quad$ Vejen. København: Gyldendal.

Orwell, George

2014 [1949] 1984. København: Gyldendal.

Piketty, Thomas

2014 Ulighedens økonomi. København: People’s Press.

Rosling, Hans med Ola Rosling \& Anna Rosling Rönnlund

2018 Factfulness. 10 grunde til at vi misforstår verden - og hvorfor den er bedre, end vi tror. København: Lindhardt og Ringhof.

Strathern, Marilyn

1988 The Gender of the Gift. Problems With Women and Problems With Society in Melanesia. Berkeley \& Los Angeles: University of California Press.

UNDP i samarbejde med Staffan Landin

2016 Bliver verden bedre? Fakta om udvikling i verden. https://docplayer.dk/20320767-

Bliver-verden-bedre-fakta-om-udvikling-i-verden.html. Hentet september 2018.

Ørntoft, Theis

2018 Solar. København: Gyldendals Bogklubber. 